\title{
Örökbe fogadjuk az iskolát! A Flensburgi Európa Egyetem tanárképzésének jó gyakorlata
}

\section{Vincze Beatrix}

\author{
az Eötvös Loránd Tudományegyetem \\ Pedagógiai és Pszichológiai Karának egyetemi docense \\ vincze.beatrix@ppk.elte.hu
}

\begin{abstract}
A tanulmány célja, hogy a tanárképzés területét érintó nemzetközi jó gyakorlatok közül bemutasson egy eredményes modellt, amelyben sikerül a hallgatókat az iskolai valósággal a képzés korai fázisában eredményesen szembesíteni. A Flensburgi Tanárképző Központ szervezésében a hallgatók egy norvég projekt mintájára egy hétre „örökbefogadnak” egy iskolát. A projektet vállaló hallgatók teljesen átveszik az iskola feladatellátását, amelynek tantestülete elutazik szakmai továbbképzésre. A tényleges projekt az előkészítéssel, megvalósitással és az értékeléssel együtt két és fél éves időszakot tesz ki, maga az egy hetes tanitás (adoptálás) egy szemeszterbe ágyazódik. A több éve folyó kísérlet sikeresen ötvöz több célkitüzést: erösíti az elmélet és a gyakorlat egységét, lehetőséget biztosit a tanárképzés kutatására, és elómozdítja a leendó tanárok szakmai professzionalizálódását és tanitási tapasztalatának bövitését, miközben az iskolai innováció motorja is (Winkel, Großmann és Grosch 2016). ${ }^{1}$
\end{abstract}

Kulcsszavak: tanárképzés, tanitási gyakorlat, tanári professzionalizáció, nemzetközi jó gyakorlat, innováció

DOI: 10.37205/TEL-hun.2019.3-4.05

\section{Az ötlettől a megvalósításig - „Az iskola örökbefogadása” projekt tartalmi elemei}

A projekt szervezője az Tanárképzés Tudományos Központja, ${ }^{2}$ amely részben a magyar Tanárképző Intézethez hasonló feladatokat lát el. Célja, hogy a tantárgyés tudományok közötti fejlesztéseket összehangolja, és a tanárképzés profiljának fejlesztési folyamatait ösztönözze, valamint projekt- és munkacsoportok kialakításával a minőségfejlesztés részét képező evaluációs folyamatokat elősegítse. A Központ legfontosabb feladatainak tekinti a gyakorlatorientált és kutatásalapú ta-

\footnotetext{
${ }^{1}$ A projekt neve: Schuladoptation, azaz az iskola örökbefogadása.

${ }^{2}$ Wissenschaftliches Zentrum für Lehrer/innen-und Lehrerbildung der Europa-Universität, ZfL, Flensburg az intézet pontos elnevezése.
} 
nulástámogatást, a kompetenciafejlesztés és a professzionalizációs folyamatok támogatását. Köztük kiemelt helyet foglal el a „Az iskola örökbefogadása” projekt.

„Az iskola örökbefogadása” projekt résztvevői azok a tanárszakos hallgatók, akik az MA-képzés 3. szemeszterének tízhetes gyakorlatát egy olyan iskolánál teljesítik Schleswig-Holstein tartományban, amely jelentkezett az adoptálási programra. Egy többhetes előkészítő szakasz után a gyakorlati szemeszter alatti blokkszemináriumon a hallgatói team egy hétre átveszi a tanítás és minden tanítási órán kívüli rendezvény felelősségét a kiválasztott iskolában. Az „adoptálási hét” alatt az egyetem oktatóinak egy csoportja figyelemmel kíséri és felügyeli a hallgatók munkáját. Az érintett iskola tantestülete pedig ezt a hetet arra használja fel, hogy az iskolafejlesztés érdekében a tantestület egy továbbképzésen vesz részt, rendszerint egy másik városban. A hét eltelte után a tantestület visszaveszi iskolai feladatait. A projekt előképe a skandináv országokban (főként a norvég gyakorlatban) már kipróbált modell (Haugaløkken és Ramberg, 2007; Schulz, 2014), amit az Európa Egyetem először 2014-2105-ben próbált ki. A projekt egészének elnevezése: „az iskola örökbefogadása”, míg ezen belül beszélünk a projekt csúcspontjáról, az úgynevezett „adoptálási hétről” (Schultz, 2014; Winkel, 2015, 2016).

A projekt célja, hogy ennek a speciális, viszonylag korai, előrehozott gyakorlat segítségével autentikus iskolai rendszerben biztosítsák a hallgatóknak, hogy eredményesen és hatékonyan élhessék meg a tanulási és tanítási folyamatot. A projekt során a leendő tanárok átfogó képet kapnak későbbi munkahelyük világáról. A hallgatók az órák megtartásával átveszik és át is élik a tanítás felelősséget, lehetőségük van arra, hogy kipróbálják magukat az iskola belső világában, és ott valódi tapasztalati élményeket szerezzenek. Így egyrészt átélik jövőbeni munkájuk komplexitását, másrészt az iskolai élet hétköznapjainak szervezésével megtapasztalják, hogy mennyire elengedhetetlen a tanári munkában a jó órák megtervezése és kivitelezése. Közvetlenül szembesülnek az iskolai élet kihívásaival, az egyéni és az intézményes szinten felmerülő iskolai és tanítási koncepciók komplex világával szembekerülve, azonnali és közvetlen megoldások keresésére, reflexiók, döntések meghozatalára kényszerülnek. A pedagógiai kompetenciák fejlesztése területén az adoptálási gyakorlat kiemelt szerepet szán:

- Az iskola belső világának komplex megismerésének a tanítási órákon belül és az órákon kívül is, az iskolai tevékenységek sokszínűségéhez alkalmazkodó tervezés és feladatmegvalósítás fejlesztésének. 
- A projekt során mentorált hallgatók tapasztalati élményeikre reflektáló írásaikkal fejlesztik pedagógiai reflexiós készségüket, későbbi tanári munkájukban hasznosítják azokat, új tanulási esélyként tudják kamatoztatni a sikereikből és kudarcaikból levont következtetéseket.

- Az adoptációs hét alatt megismerik a tanári munka szakmai részeinek olyan gyakorlati elemeit, mint a tanítás előkészítését, szervezését, irányítását és a tanítást követő evaluációs folyamatokat, ${ }^{3}$ illetve a tanítási órán és az iskola világán túlmutató mindennapos pedagógiai tevékenységek széleskörü skáláját.

- A projekt az örökbefogadási héttel a szaktárgyi és a szakdidaktikai ismeretekre alapozott, tudományosan kidolgozott iskolai gyakorlatot kíván biztosítani, amely biztosítja a tanítás komplex élményvilágát.

Az örökbefogadott iskola szintén jelentős esélyekhez jut. A projekt lehetőséget biztosít az iskolafejlesztésre, az innovatív ötletek beépítésére, az iskolai profil (pedagógiai program) gazdagítására. A flensburgi Európa Egyetem tudományosan is figyelemmel kíséri a projektet, és a megszerzett tapasztalatokat és új ismereteket az iskolai gyakorlat továbbfejlesztésében hasznosítja.

Az egyetem az iskola örökbefogadási programot egy országok közötti továbbképzésben is hasznosítja (SATE - School Adoptation in Teacher Education), amelyet az Erasmus+ program is támogat. A jelenleg meghirdetett programra az iskolák 2019. június végéig jelentkezhettek. A kiválasztott iskolákat a Tanárképző Központ szeptember elejéig tájékoztatja az eredményekről. December közepén zárul a hallgatók jelentkezésnek időszaka, és néhány nappal később már meg is kapják a visszajelzést azok, akik bekerültek a programba.

A tanárképzés innovációjának sajátos modellje tehát arra épít, hogy az egyetemi oktatókból álló szupervíziós csoport eredményesen tudja bevonni a fejlesztésbe mind a tanárképző intézetet, mind az iskolát, mind a hallgatókat (Hascher, 2011; Weyland, 2014). Egy többfázisú, egymást támogató, kiegészítő iskolafejlesztés valósul meg, amelynek haszna közvetlenül megjelenik a munkaerőpiacon is. A projekt előtérbe helyezi az élményszerúséget, a spontaneitást, a reflektivitást, a stressz kezelését, megelőzve az iskolai gyakorlatot, lehetőséget ad a hallgatóknak, hogy kipróbálják kompetenciáikat. A leendő tanárokat megismerteti, szembesíti

\footnotetext{
${ }^{3} \mathrm{Az}$ iskolák evaluációs rendszerét a Schleswig-Holsteini Iskolák Minőségfejlesztési Intézete dolgozta ki, a projekt során az egyetem Tanárképző Központja folyamatosan együttműködik az Intézettel, azzal a céllal, hogy az tanárképzést és annak innovációját tudományosan elemezze, és a tapasztalatok közvetlenül hasznosuljanak.
} 
az iskola valóságával, és a tapasztalati tudáson át mélyíti el az elméletet, épít az egymástól való tanulásra.

\section{Miért indokolt az iskolai gyakorlatra építő projekt?}

Több nemzetközi tanulmány felhívja a figyelmet arra, hogy a 21. század munkaerőképzése, így a tanárképzés maga is gyökeresen átalakul. A jövő oktatása egyre kevésbé tervezhető, kiszámítható, ami a reflexiós készségek hatékony fejlesztését teszi szükségessé (Darling-Hammond, 2006; Shulman, 2013). Inkább a kórházi „sürgősségi ellátás” jellemzi, ahol másodpercek alatti döntésekre van szükség. Mindezt betudhatjuk a globalizációs tendenciák fejlődésének, a társadalmi változásoknak, a tanulásról és a tanításról kialakult új elméletek és felfogások napról napra történő gazdagodásának. Számolnunk kell azzal is, hogy tanulók és a pedagógus közötti kulturális, szocioökonómiai különbségek nem tűnnek el. A tanártól egyre inkább elvárt, hogy professzionális szakértő, a tanulás-tanítási elméletek, stratégiák és taktikák ismerője legyen (Shulman, 2013). Az új paradigma szerint a tanításról a tanulásra kerül a hangsúly, meghatározó szerepet kap az élethosszig tartó tanulás (LLL, Lifelong learning), a kutatójellegű (felfedezve történő) tanulás, az experimental learning és a reflektív gondolkodás. A tanárképzés megújítása számos modellt teremtett meg, amelyek többségükben kiemelt szerepet szánnak a tanítási gyakorlatnak, a reflexiós készségek fejlesztésnek és a tanári portfóliónak (Hudson és Zgaga, 2008; Rolff, 2013; Schulz, 2014; Bildungsbericht, 2018).

Érdemes megvizsgálni, hogy mit ad az „örökbefogadási projekt” a hallgatóknak, illetve a képző intézménynek és az iskolának. Miért jó a hallgatónak, hogy önként vállalja ezt a hosszú, képzésbe ágyazott projektet? A projekt biztosítja az iskolai (aktuális) kihívások szituatív megélését és azok megoldását, az azonnali reflektálást és a velejáró felelősségvállalást, amely lehetővé teszi az alkalmazkodási készség és a cselekvésorientált tanulási stratégiák fejlesztését. A pedagógiai kompetenciák komplex (tovább)fejlesztése mellett lehetőség van a hiányok felmérésére, az egyéni sajátosságok elemzésére, mindezt egy holisztikus tanítási élmény keretén belül, tehát valóságos tanítási helyzetben. A tanárjelölt közvetlenül tanulhat a sikereiből és kudarcaiból, az élményeken túl közvetlen visszajelzéseket kap a diákoktól és a mentoroktól. Ez kaland és kihívás is a hallgatók számára, mindamellett fontos szakmai referenciákat is szereznek a projekt teljesítésével. A hallgató komplex módon, az elmélet és a gyakorlat közvetlen összekapcsolásával tudja fejleszteni és elmélyíteni pedagógiai reflexiós kompetenciáit. 
Miért hasznos a projekt az egyetemnek, a képző intézménynek, amely egyébként átháríthatná a tanítási hivatás gyakorlását a 2. képzési szakaszra (a Lehramt időszakára)? Az egyetem, és a Tanárképző Központ fontosnak tartja, hogy már a képzés során visszajelzést kapjon egy olyan, általa menedzselt konkrét tanítási gyakorlatról, amelynek tapasztalatait tudományos igénnyel feldolgozhatja, és ezzel támogatja az iskolai nevelés szakmai és szakmódszertani megalapozását, illetve impulzusokat kap a tanárképzés további fejlesztéséhez. Az intenzív tudományos evaluáció és folyamatkísérés lehetővé teszi, hogy az iskola adoptációs projekt eredményeiből adódó új ismereteket az iskolai gyakorlat bizonyos területein, például a tanácsadói kompetenciák vagy a hallgatók reflexiós készségeinek további fejlesztésében hasznosítsák. Az Európa Egyetem célja, hogy a projekt eredményeit elemezve vizsgálja a hallgatókat ért stresszhatásokat, illetve azt, hogy mely faktorok járulnak hozzá leginkább a komplexitás élményéhez. A pályakezdés elején álló tanárjelöltek esetében eddig olyan kihívások kerülhetnek a szakmai és tudományos érdeklődés középpontjába, amelyek eddig rejtve maradtak, vagy kevesebb figyelmet kaptak. Ezen új kihívások, szempontok becsatornázhatók a tanárképzés különböző intézményrendszereibe, például az egyetemi képzésbe. A projekt és tapasztalatai tovább erősítik a kutatásalapú tanárképzés folyamatos megújulását.

Miért vállalja egy iskola ezt a kockázatos örökbefogadási procedúrát? Az egyhetes továbbképzés és annak az értékelése szintén kiválóan hozzájárul ahhoz, hogy az iskola tantestülete új impulzusokat gyüjtsön, felvértezze magát proaktív módon a kiégés ellen, és kellően megújuljon. A tantestület segítséget kap ebben a folyamatban (a tervezésben és a kivitelezésben) az egyetem oktatói teamjétől. Mivel az iskolafejlesztés hosszabb folyamat - ebben az adoptációs hét egy csomópont, amelynek visszacsatolásaként felhasználhatók a hallgatói produktumok, új technikák és módszerek, a reflexiók, a támogató képző tanácsadói tevékenysége, a tudományosan megalapozott, tervezett modellben rejlő frissítő erő (flow), a projekt tudományos igényű evaluációja. Felmerülhet bennünk a kérdés, hogy vajon milyen számban jelentkeznek az iskolák a projektre? Mennyire vállalkozószellemüek a tantestületek? Az iskola kiválasztása pályázat útján történik, és az eddigi tapasztalatok azt mutatják, hogy a projektnek kiváló visszhangja van, az utóbb meghirdetett projektekre 10-15 iskola is pályázik. A tantestületek is jól érzékelik a projektben rejlő megújulási lehetőséget, a spontán és tudatos elemekből adódó iskolafejlesztési gyakorlat lehetőségét (Winkel, Großmann és Gosch, 2016; Winkel és Gosch, 2017). 


\section{A projekt tartalmi elemi: kísérő szeminárium, reflexiós kör és hálózati csoport}

A kísérő szeminárium közvetíti a hallgatók számára a tartalmi elemeket, amelyeket az iskolapedagógia gyakorlati szemeszterének curriculumában rögzítettek. Továbbá olyan elemek gazdagítják a szemináriumot, amelyek az örökbefogadási héthez szükséges készségeket és képességeket feltételeznek. A kurzus keretein belül megismerik a hallgatók a projekt tartalmi elemeit, az iskolai programot és a tervezést. Kitérnek olyan témákra, mint a különböző szocioökonómiai státuszú diákokkal való együttműködés keretei az iskolai munkában, az iskolai jog, az iskola kommunikációs formái, működése és az iskolai neveléssel járó kihívások.

A szemináriumot vezető rendszerint bekapcsolódik az adoptációs hét reflexiós körébe is, amely egyébként másik kísérő eleme az egyhetes projektnek. A nap végén kerül rá sor, és három funkciója van: 1. teret ad a közvetlen hallgatói megnyilvánulásoknak; 2. kölcsönös diszkussziós lehetőséget biztosít valamennyi résztvevőnek, azért, hogy a legjobb cselekvési alternatívák kerülhessenek kiválasztásra, és ezeket alkalmazzák; 3. a reflexiós körben a közvetlen iskolai tapasztalat alapján felbukkanó problémák egy tágabb, tudományos kontextusban válnak értelmezhetővé.

Az iskolai adoptációban hallgatói IQSH-hálózati csoportot képeznek, azaz a Schleswig-Holsteini Iskolák Minőségfejlesztési Intézetének hálózatát gazdagítják. A hálózati csoport célja, hogy a gyakorlati szeminárium alatti megfigyeléseket, elemzéseket és reflexiókat, a tanítási folyamat során született terveket és a megvalósításuk tapasztalatait szisztematikusan feldolgozzák. A hallgatók saját tanítási praxisukban megélt élményei reflexióikat elmélyíthetik, tapasztalataikat az egyetemen tanult tudományos modellekkel és feltevésekkel összevethetik. A saját és mások tanítási tapasztalatainak, reflexióinak feldolgozásával - egyedi esetek, tervek, videófelvételek elemzésével - jelentősen hozzájárulnak a képzés minőségfejlesztéséhez. A hallgatók és az iskolában tanítók közreműködésével értékelés is születik az iskola átvétele előtti és az átadás utáni időszakról (az adoptációs hét közben végbement változásokról). Több célja is van ennek az értékelési folyamatnak: 1. a hallgatói és a tanári szerepek tisztázása az adoptációs hét után; 2. a megfigyelt diákok nem értékelt kompetenciáinak számbavétele; 3. a projekthét során tapasztalt „erősségek” visszajelzése a diákoknak. Ehhez előzetesen több feladatot is kidolgoztak, hogy például megfigyelhessék a tanulók motorikus képességeit, kreativitásukat, kommunikációjukat, szociális kompetenciáikat, tervezési készsé- 
güket. Hogyan küzdenek meg a nehézségekkel, milyen megküzdési stratégiáik vannak, milyen cselekvési mintáik vannak a vezetői szerep átvételében és átadásban. Az egész evaluációs folyamat a Minőségfejlesztési Intézettel történő folyamatos kooperációban történik (Winkel, Großmann és Gosch, 2016).

\section{„Az iskola örökbefogadása” projekt menete}

$\mathrm{Az}$ iskolákat és a hallgatókat is pályázat útján választják ki. Minden részvevő önkéntesen vállalja a projektet. Az iskoláknak a tantestület, a szülők, a fenntartó, sőt a minisztérium hozzájárulását is meg kell szerezni ahhoz, hogy részt vehessenek a projektben. A hallgatók motivációs levelet írnak a pályázathoz, és egy kérdőivet töltenek ki. Ezt megelőzően kellő tájékoztatást kapnak a projekt menetéről, amelyre a projekt korábbi részvevői is meghívást kapnak, hogy élménybeszámolóikkal motiválják a jelentkezőket. A kiválasztást egy grémium végzi, amelynek tagjai az egyetem oktatói, minisztériumi szakértők, a Schleswig-Holsteini Iskolák Minőségfejlesztési Intézetének tagjai. A válogatás után vezetői team megalakításra kerül sor, amelynek tagjai képviselik a hallgatókat (a projekt leendő tanárait), az iskolát, az egyetemet és a Minőségfejlesztési Intézetet. A vezetői team többször találkozik az előkészítési folyamatban és az adoptálási hét alatt, szükség szerint reagál a felmerülő problémákra. A hallgatók és a tantestület az iskolában találkozik, a hallgatókat szakspecifikusan rendelik a tanárokhoz.

A projekt során a hallgatókból önkéntesen verbuválódott (kiválasztott) tantestület egy hétre teljeskörű felelősséggel átveszi a tanítás teljes menetét, az iskolai élet valamennyi nevelő-oktató feladatát. A hallgatóknak ezért az iskolai rutin valamennyi szegmensével meg kell ismerkedni, és fel kell készülniük a váratlan helyzetekre is. A hét során ők látják el a teljes felügyeletet, valamennyi tanítási órát, foglalkozást, az étkeztetést, a szülőkkel történő kommunikációt. Az iskolavezetést teljes jogkörrel átveszik (az egyetemi oktatói állandó jelenléte és mentorálás mellett), ezért nagyon fontos, hogy az iskolajogi kérdésekben is felkészültek legyenek. Miután a teljes tantestület elutazik továbbképzésre, a biztonság kedvéért egy szomszédos (közeli) iskolaigazgató kap felhatalmazást arra, hogy bármilyen extrém esetben az iskolavezetést ideiglenesen átvegye. Ilyenre az eddigi norvég és német projektek során nem került sor (Winkel, Großmann és Gosch, 2016; Winkel és Gosch, 2017).

A teljes projekt időtartama két és fél év (három szemeszter). Az első évben az iskolapedagógia keretén belül egy kísérő szemináriumon és a gyakorlati szemesz- 
ter alatt felkészítik a hallgatókat az iskola adoptációra. Az első év februárjában kerül sor a hallgatói tájékoztató rendezvényre, áprilistól májusig tart a személyes információk kielégítése és az érdeklődő iskolák tájékoztatása. Szeptemberben zárul az iskolák számára a pályázat beadása. Szeptemberben és októberben kerül sor a hallgatói pályázatok meghirdetésre. Ezt követi novemberben a hallgatók kiválogatása, decemberben a résztvevők közös megbeszélései és találkozásai, amelyek feladata a közös célok megfogalmazása. Újabb tájékoztatók után kezdődik az MA-s hallgatók első gyakorlati szemináriuma, amelynek során a hallgatók felkészülnek az adoptációs hétre. Januárban hallgatói találkozó, februárban a vezetői team, márciusban újabb hallgatói, áprilisban és májusban hallgatói és vezetői találkozók következnek. Júniusban a kísérő szeminárium keretén belül a hallgatók találkoznak a tantestülettel, szeptemberben pedig a szülőkkel is. Decemberig készülnek a hallgatók az örökbefogadási hétre, amelyet általában december elején tartanak, de szükség szerint lehet november végén vagy januárban is. A gyakorlati blokk novemberben kezdődik és januárban ér véget.

A német nyelvű tartományokban a gyakorlati szemeszter (benne a Praxisblock $)^{4}$ célja, hogy közelebb hozza egymáshoz az egyetem és az iskola világát. Szakdidaktikai tanulmányaikat a hallgatók az iskola világában egészítik ki, és fejlesztik tovább. Általában három napot töltenek az iskolában (heti 15 órát), ahol bizonyos tanítási egységekben mentori segítséggel egyedül vagy párban ki is próbálják magukat, tanítanak szakjaikban. Bekapcsolódnak a tanítási órákon kívüli nevelési feladatokba és iskolai rendezvényekbe. A gyakorlat során készült dokumentumok a portfólió részét képezik. A harmadik évben a januártól májusig tartó időszakban kerül sor az evaluációra. A portfólióval kapcsolatos és a kutatási feladatok elvégzésre, az projektet záró értékelésre és a jelentés elkészítésére (Winkel, Großmann és Gosch, 2016).

\section{Eredmények}

A flensburgi egyetem először 2014-2015-ben vállalta a projektet, 22 hallgató vett benne részt. A 200 tanulóval müködő fruerlundi Általános Iskolában került sor a megvalósítására, amely rendkívül pozitív visszhangot és nagy média nyilvánosságot is kapott. A diákok nevében nyilatkozó Calle Wölk a következő szavakkal ösz-

\footnotetext{
${ }^{4}$ A gyakorlati szemeszter része a Praxisblock (gyakorlati blokk/blokkszeminárium), amely a 10 hetes iskolai gyakorlatot jelenti.
} 
szegezte projektet alatt szerzett élményeket: „A tanárok most fiatalabbak, és többet játszanak velünk" (Spenger, 2015).

Az Európa Egyetem által adaptált projekt eredményesen beépült a tanárképzés minőségfejlesztését szolgáló kezdeményezések közé. A szerepcserén alapuló modell az iskola örökbefogadásával változatlanul népszerủ, és folyamatosan meghirdetik. A kutatási eredmények a stressztapasztalatok kapcsán azt mutatták, hogy a tanárok számára a legnagyobb gondot az osztálytermen belüli interakciók kezelése, a helyzetek beazonosítása, továbbá általában a munkaterhelés növekedése jelenti. Illetve a tartalomelemzések arra is rávilágítottak, hogy a gyakorlat során felmerülő komplex szituációk pozitív kihívásként élhetők meg, köszönhetően annak, hogy a projekt kielégítően strukturált előkészítési és mentorálási keretet biztosít (Bach, 2015).

A projekt irányítójának, a Tanárképző Központnak fontos partnere az EULE (Oktatásfejlesztés, tanulási kultúra és evaluáció intézete), amely komoly könyvés médiatárral és módszertani segédanyaggal támogatja a tanárokat. Az EULE rendszeresen szervez szakmai napokat, konferenciákat és workshopokat, amelyekkel folyamatosan biztosítja a tanárok szakmai továbbképzését. Az EULE együttműködik a Minőségfejlesztési Intézettel, az IQSH-val. A kapcsolattartást a partneriskolák hálózata (Netzwerk der Kooperationsschulen) segíti (Schulz, 2014; Winkel, 2015; Winkel, Großmann és Gosch, 2016; Winkel és Gosch, 2017).

\section{Összegzés}

Áttekintve a tanárképzési modelleket több típussal találkozunk. Léteznek olyan megoldások, ahol kizárólagosan csak az egyetem képezi a tanárt, és a gyakorlat a képzőn kívül van. A delegált (kihelyezett gyakorlat) mellett, másik lehetőség a kooperatív modell (az egyetem és az iskola egyenrangú félként együttmüködik együtt). Speciális innovatív modellnek tekintjük az adoptáló modellt. Fontos szerepet kapnak az egyetemi iskolák, amelyek az új fejlesztések terepei, az implementálásának színterei, ilyen például Bielefeld. A két utóbbi modell - elkerített fenntartható tanulási arénákként értelmezhetők, az úgynevezett „tanuló iskola” megtestesítői (Haugaløkken és Ramberg, 2007).

$\mathrm{Az}$ iskolai gyakorlatok régóta képezik vita tárgyát a pedagógiai irodalomban. Fontosságukat senki sem kérdőjelezi meg, időbeni és térbeli elhelyezkedésük változatos mintákat mutat. Az iskolában töltött szemeszterrel szemben támasztott legevidensebb, ugyanakkor a legjelentősebb elvárás a gyakorlatorientáltság. 
Mindamellett a pedagógiai diszkusszióban felmerül a jelentősége annak is, hogy a tanítási tapasztalat mellett a szakmai orientáció is éppúgy latba kell, hogy essen. A szakirodalomban többféle kommunikáció, eltérő álláspontok és különböző érzelmi kötődések formájában értelmezik a szakmai gyakorlatot. Az iskolai gyakorlat a legjelentősebb gyakorlatorientált makroforma, amely mellett (sőt gyakran a makroforma részeként) említésre kerülnek a gyakorlatorientált mikroformák, például a hospitálás, a videófelvétel és az esetelemzés (Weyland, 2014; Ramberg és Haugaløkken, 2013).

A tanárképzés kapcsán már a 2000-es évek legelején megfogalmazott kritikák felhívták a figyelmet arra, hogy az egyetemi gyakorlatok nem kapcsolódnak kellően egymáshoz, nem biztosítanak folyamatos tapasztalati élményt. A gyakorlatok nincsenek kellőképpen beágyazva a szaktárgyi tanulmányokba, nem befolyásolják a szakmai iránti elkötelezettséget. A vizsgák nem vagy alig vonatkoznak a gyakorlatok eredményeire, az osztott (kétfázisú) egyetemi szakmai gyakorlatok nem épülnek kellően egymásra, egyik sem kellő arányban kapcsolódik a szakmai kompetenciák fejlesztéshez. Az iskola és az oktatás szisztematikus fejlesztésének hangsúlyozása arra is felhívta a figyelmet, hogy az innovációs folyamatoknak kötődniük kell a képzési modellekhez is (Rolff, 2013; Weyland, 2014).

Mindezek tükrében megfontolandó, hogy milyen új megoldások irányába keres megoldást és megújulást a tanárképzés (Horváth H. és Pálvölgyi, 2013). A képzésnek reflektálni kell a napi kihívásokra, és a külföldi jó gyakorlatok mellett számba kell venni azokat a hazai már müködő formákat (terepgyakorlatokat, érzékenyítő programokat, önkéntes közösségi szolgálatot), amelyek elősegítik a leendő tanárok szakmai kompetenciáinak fejlődését, szakmai identitásnak erősödését. Szem előtt tartva, hogy a munkaerőpiacnak alapvetően olyan szakmai utánpótlásra van szüksége, amelynek kompetenciáira építhet. McKinsey szerint a tanároktól függ az oktatás minősége, másrészt kiemeli, hogy „Nem diplomákra, hanem készségekre és képességekre van szükségünk”s (Halász 2012; McKinsey, 2007).

${ }^{5}$ A mondat angol eredetije a következő: "We do not need qualifications, we need skills." 


\section{Irodalom}

Bach, Andreas (2019): School Adoption by School-University Partnerships - an example from Germany. In: Journal of Education for Teaching: International Research and Pedagogy. 45. évf., 2. sz. 1-16.

Bildungsbericht in Deutschland 2018: Bundesministerium für Bildung und Forschung. Media GmbH, Bielefeld. 151-170. https://

www.bildungsbericht.de/de/nationaler-bildungsbericht (Letöltés: 2019.november 15.)

Darling-Hammond, Linda (2006): Powerful Teacher Education: Lessons from Exemplary Programs. Jossey-Bass, San Francisco.

Halász, Gábor (2008): A pedagógus számít. http://halaszg.ofi.hu/download/A_pedagogus_szamit.htm\#_ftn2 (Letöltés: 2019. november 15.)

Hascher, Tina (2011): Vom Mythos Praktikum.... und der Gefahr verpasster Lerngelegenheit.

file://C:/Users/Samsung/AppData/Local/Temp/Vom22MythosPraktikum22_Hascher_2011.pdf (Letöltés: 2019. november 15.)

Haugaløkken, Ove Kr. - Ramberg, Per (2007): Autonomy or control: Discussion of a central dilemma in developing a realistic teacher education in Norway. In: fournal of Education for Teaching: International Research and Pedagogy, Vol. 33, February.

Horváth H., Attila - Pálvölgyi, Krisztián (2013): Együttmüködések támogatása a pedagógusképzésben - a kötetben tárgyalt fejlesztés tágabb kontextusa. In: Horváth H., Attila, Pálvölgyi, Krisztián, Bodnár, Éva és Sass, Judit (szerk.): A tanárképzés jövőjéröl. Átívelések. 11-20. http://ofi.hu/sites/default/files/attachments/a_tanarkepzes_jovojerol_2.pd (Letöltés: 2019. november 15.)

Hudson, Brian - Zgaga, Peter (2008): Teacher education policy in Europe: a voice of higher education institutions. https:/www.researchgate.net/publication/

228697673_Teacher_education_policy_in_Europe_a_voice_of_higher_education_institutions (Letöltés: 2019. november 15.)

McKinsey \& Company (2007): Mi áll a világ legsikeresebb iskolai rendszerei teljesítményének hátterében? http://oktatas.mholnap.digitalnatives.hu/images/Mckinsey.pdf (Letöltés: 2019. november 15.)

Ramberg, Per - Haugaløkken, Ove Kr. (2013): Internationale Perspektiven: School adoption - Realistic teacher education in the intercept between theory and practice, 60. évf. March. 1. https://doi.org/10.14220/mdge.2013.60.1.56

Schulz, Wolfgang (2014): Studierende machen Schule! Das Modell „Schuladoption“ an der Europa-Universität Flensburg. 
https://www.uni-flensburg.de/fileadmin/content/portale/lehrerbildung/dokumente/forschung-und-entwicklung/adoption-konzept-deu-2015-05-06.pdf (Letöltés: 2019. november 15.)

Rolff, Hans-Günter (2013): Schulentwiklung kompakt. Beltz, Weinheim, Basel. 1130.

Shulman, L. (2013): Theory, practice and the education of professionals. The Elementary School fournal, 98. évf., 5. sz. 511-526.

Spenger, Uwe (2015): Rollenaustausch in Fruerlund. https://www.uniflensburg.de/fileadmin/content/portale/lehrerbildung/dokumente/presse/ 01.12.2015-fla-rollentausch-in-fruerlund.pdf (Letöltés: 2019. november 15.)

Winkel, Jens (2015): Jahresbericht des wissenschaftlichen Zentrums für Lehrerinnen-und Lehrerbildung der Europa-Universität, Flensburg. Flensburg, EUF.

Winkel, Jens - Großmann, Kirsten - Gosch, Johanna (2016): Schuladoptation. Flensburg, EUF. https://www.uniflensburg.de/fileadmin/content/portale/lehrerbildung/dokumente/presse/konzept-schuladoption-englisch-final-internet.pdf (Letöltés: 2019. november 15.)

Winkel, Jens (2016): Jahresbericht des wissenschaftlichen Zentrums für Lehrerinnen-und Lehrerbildung der Europa-Universität, Flensburg. Flensburg, EUF.

Winkel, Jens - Gosch, Johanna (2017): Über die Schuladoptation. (Interjú, készítettte: Vincze Beatrix), Flensburg EUF.

Weyland, Uwe (2014): Schulische Praxisphasen: Professionalisierung oder deprofessonalisierende Wirkung? https://www.bwpat.de/profil-3/weyland (Letöltés: 2019. november 15.) 


\section{We are adopting the school! Good practice at the University of Europe in Flensburg}

The aim of the study is to present an effective model of international good practice from teacher training, in which students are effectively confronted with school reality at an early stage of training. Organised at the Flensburg Teacher Training Centre, students "adopt" a school for a week, modelled on a Norwegian project. The students who undertake the project will take full responsibility for the school, whose teachers will travel for further vocational training. The actual project, together with preparation, implementation and evaluation, is a two-anda-half-year period, with one week's teaching (adoption) itself embedded in one semester. The multi-year experiment successfully combines several objectives: strengthening the unity of theory and practice, providing opportunities for research into teacher training and promoting the professionalisation and educational experience of prospective teachers, while also being the engine of innovation in schools (Winkel, Großmann és Grosch 2016).

Keywords: teacher training, teaching practice, teacher professionalisation, international good practice, innovation 